\title{
MEDIAÇÃO ESCOLAR: CONTRIBUIÇÕES DA PSICOLOGIA Á LUZ DOS DIREITOS HUMANOS
}

\author{
Apresentação: Relato de Experiência \\ Joanita de Souza Leão Guardiola ${ }^{1}$; Janaina Cristina Cabral da Silva Girão²; Maria de \\ Jesus Moura ${ }^{3}$
}

\section{Introdução}

Têm sido frequentes na mídia os debates a cerca dos acontecimentos violentos que tem se manifestado no âmbito escolar, tais como: brigas, preconceitos, discriminação, humilhação, exclusão e negação da cidadania. Afetando toda a comunidade escolar (educadores, funcionários, gestores, alunos e familiares). Tais problemas têm suscitado inúmeros debates referentes ao papel da escola diante de tanta violência, visto que, a escola tem um papel singular na formação de identidade do ser humano, por ser um espaço de aprendizagem e de socialização. De fato essa realidade não pode virar rotina tampouco normalidade. Aliado a esse fato se faz prioridade à implantação de projetos preventivos contra a violência escolar.

\section{Relato de experiência}

Embora não tenha sido realizado para este trabalho, uma pesquisa de campo pode-se apresentar a seguir a titulo de exemplo uma experiência referente às pesquisadoras. Por seis meses vivenciou-se a experiência de mediadoras de conflito em uma escola pública de Recife-PE, por meio de um programa do governo, que surgiu como prevenção da violência no ambiente escolar "Promotoras da paz".

A escola trabalha com turmas de séries iniciais do ensino fundamental. A finalidade do programa era promover a paz na escola por meio de intervenções educativas, tais como: atividades lúdicas, seminários, capacitações ou palestras conduzidas por voluntários convidados da rede sócios assistencialistas e pelos promotores da paz.

${ }^{1}$ Faculdade Estácio do Recife; joanitadesouza@ hotmail.com 
Com temas escolhidos sob a aprovação e supervisão dos gestores e professores, conforme a demanda. Tais atividades eram pensadas para toda a comunidade escolar de acordo com as dificuldades expostas. Pode-se compreender que as estratégias da Psicologia são harmônicas com os princípios da mediação, uma vez que promove, ao sujeito, o exercício da cidadania e dos direitos humanos, pois tende a lhe dar autonomia e promover a prática do diálogo para a compreensão dos conflitos e o respeito pleno aos envolvidos. Nesse sentido, ficou claro a necessidade de estudos a cerca da mediação escolar, pois essa é distinta a mediação jurídica, por demandar ações socioeducativas. Considerando o que foi dito, é valido pontuar que, para que a cultura de paz faça parte do cotidiano da escola, é essencial que o sujeito reconheça a si mesmo e o outro, enquanto sujeitos de direitos; isso possibilitará uma melhor abertura para o diálogo e o respeito mútuo.

\section{Considerações finais}

Diante do que foi visto, foi observado que o conflito é natural e inerente ao ser humano, pois nos encontramos em constante relação. É preciso entendê-lo na sua totalidade sem negar a sua existência. Promovendo o diálogo de forma educativa, sem esconder sua face. Do contrário o conflito surgirá cedo ou tarde, de forma violenta. Compreende-se que de fato não somos educados para lidar com o conflito, por isso a escola encontra-se em dificuldades para entendê-lo. Portanto, destaca-se a importância da mediação de conflitos dentro da escola, por julgar o mediador um terceiro imparcial e especializado. No entanto, o diferencial seria munido dos conhecimentos da Psicologia, por acreditar que assim facilite no processo da mediação, visto que o arcabouço teórico da Psicologia possui estratégias que facilitam na compreensão dos conflitos, já que segundo Freud (1930) este é constituinte do ser. Sendo ele agente coconstrutor no processo da resolução dos conflitos, como um processo de aprendizado e responsabilidade. A relevância deste trabalho, de cunho reflexivo e informativo, é de demostrar como a Psicologia pode contribuir no desenvolvimento social e emocional de toda a comunidade escolar, ademais, tornando a relação interpessoal, no ambiente escolar harmoniosa.

\section{Referências}

SIGMUND, Freud. O futuro de uma Ilusão. Rio de Janeiro: Ed. Imago, 1927. SIGMUND, Freud. O mal-estar da civilização. Rio de Janeiro: Ed. Imago, 1930. 